\title{
The secondary vascular system of Actinopterygii: interspecific variation in origins and investment
}

Published online: 28 November 2003

(C) Springer-Verlag 2003

\begin{abstract}
Vascular casts of 3 species of Chondrichthyes, 1 of Dipnoi, 1 of Chondrostei and 14 species of the Teleostei were examined by light and scanning electron microscopy in order to give a qualitative and quantitative analysis of interarterial anastomoses (iaas) that indicate the presence (or absence) of a secondary vascular system (SVS). Anastomoses were found to originate from a variety of different primary blood vessels, many of which have not been previously identified as giving rise to secondary vessels. Segmental arteries derived from the dorsal aorta and supplying body musculature were major sites of origin of the SVS, although there was considerable variation in where, in the hierarchy of arterial branching, the anastomoses occurred. The degree of investment in a SVS was species specific, with more active species having a higher degree of secondary vascularisation. This difference was quantified using an absolute count of iaas between Anguilla reinhardtii and Trachinotus baillonii. A range of general features of the SVS is also described. No evidence of iaas was found on the coeliac, mesenteric or renal circulation in any species. Evidence of iaas was lacking in the dipnoan and chondrichthyan species examined, suggesting that a SVS is restricted to Actinopterygii. The presence and distribution of a SVS does not appear to be exclusively linked to phylogenetic position, but rather to the physiological adaptation of the species.
\end{abstract}

Keywords Secondary vessels - Secondary circulation . Vascular casting · Phylogeny · Investment . Chondrichthyes · Chondrostei · Holostei - Teleostei

The online version of the original article can be found at http://dx.doi.org/10.1007/s00435-003-0083-2

P. V. Skov $(\bullet)$ M. B. Bennett

School of Biomedical Sciences,

Department of Anatomy and Developmental Biology,

The University of Queensland,

4072 St. Lucia, Queensland, Australia

e-mail: peter.skov@uq.edu.au

Tel.: +61-7-33652702

Fax: +61-7-33651299

\section{Zoomorphology (2003) 122:181-190}

Owing to unfortunate technical problems, inappropriate symbols appeared throughout the text, making it necessary to reprint the article.

\section{Introduction}

The presence of a secondary vascular system (SVS) was initially documented for two species of Teleostei by Burne (1926, 1929), through dye injection studies in Lophius piscatorius Linnaeus, 1758 (anglerfish) and Gadus morhua Linnaeus, 1758 (Atlantic cod). Burne described a system of fine vessels associated with the (primary) vasculature of these two species, and suspected that these vessels constituted a separate vessel system. The very low haematocrit of the SVS (approximately 1\%) combined with the fact that no arterial connection to the primary vasculature could be demonstrated, forced him to term these vessels 'lymphatic'. His findings were left unexplored until Vogel and Claviez (1981) rediscovered the SVS and demonstrated the connection to the primary vasculature, the interarterial anastomoses (iaas).

The implications of a systemic SVS in Actinopterygii has been discussed widely during the last decade, and its unequivocal presence has been documented in a number of species (Vogel and Claviez 1981; King and Hossler 1986; Olson et al. 1986, 1990; Steffensen et al. 1986; Lahnsteiner et al. 1990; Dewar et al. 1994; Munshi et al. 1994; Chopin and Bennett 1996; Chopin et al. 1998) and on a variety of blood vessels. The predominant method for its visualisation has been through vascular casting, where injection of an acrylic polymer leaves a rigid three-dimensional structure of the vascular system for study once the surrounding tissues have been corroded away. However, the transparent tissues of Kryptopterus bichirrhis (Valenciennes, 1840) (glass catfish), allowed Steffensen et al. (1986) to describe the SVS of this species in vivo, by light microscopy.

Secondary vessels arise directly from the primary vasculature via numerous iaas. These funnel-shaped openings 
typically arise from the walls of arteries $50 \mu \mathrm{m}$ or greater in diameter (Olson 1996). The opening into an anastomosis is surrounded by numerous cells bearing microvilli (Lahnsteiner et al. 1990), each approximately $10 \mu \mathrm{m}$ long (Vogel 1981), protruding into the lumen of the anastomosis, and may also be present 'upstream' from the origin of anastomoses (Vogel 1981). The function of the microvilli is unknown, but it has been suggested that they may be responsible for plasma skimming (Vogel 1981), or they may possess adhesive properties to ensure that some blood cells pass through to the SVS (Steffensen and Lomholt 1992). Interarterial anastomoses taper to become small bore vessels that follow a tortuous path over the following $200-300 \mu \mathrm{m}$ before anastomosing with neighbouring vessels to form secondary vessels (Olson 1996). In Arius graeffei Kner and Steindachner, 1867 (fork-tailed catfish), secondary vessels form capillary beds that supply the periphery of the red muscle (Chopin and Bennett 1996), while in Tandanus tandanus (Mitchell, 1838) (eel-tail catfish) secondary capillary beds supply the skin (Chopin et al. 1998), before draining into the cutaneous veins. In Blennius pavo (Risso, 1810) (peacock blenny) and Zosterisessor ophiocephalus (Pallas, 1814) (grass goby) secondary vessels do not form capillary beds, but reportedly empty directly into secondary veins (Lahnsteiner et al. 1990). A cutaneous capillary supply is assumed to be typical for teleosts (Vogel 1985).

Burne's descriptions also suggest that a secondary vessel system occurs in the mouth and head regions, yet no attempts have been made to determine which primary vessels supply this part of the secondary vasculature (Burne 1926, 1929). The aim of this study is to undertake a detailed examination of vascular casts from a wide range of phylogenetically diverse species, with represen- tation from the Chondrichthyes, Chondrostei and Teleostei, to determine the presence or absence of a SVS, and explore any interspecific differences in the frequency of origin of iaas and the vessels of their origin.

\section{Materials and methods}

Animals

Pseudocaranx dentex (Bloch and Schneider, 1801) (silver trevally), Echeneis naucrates (Linneaus, 1758) (slender suckerfish), Gymnocranius audleyi (Ogilby, 1916) (collared sea bream), Lutjanus fulviflammus (Forsskål, 1775) (blackspot sea perch), Scarus schlegeli (Bleeker, 1861) (Schlegel's parrotfish), Halophryne diemensis (Leseur, 1824) (banded frogfish), Conger cinereus Rüppel, 1830 (black-edged conger) and Hemiscyllium ocellatum (Bonnaterre, 1788) (epaulette shark) were caught by angling or hand-net on Heron Island Reef $\left(23^{\circ} 27^{\prime} \mathrm{S} 151^{\circ} 55^{\prime} \mathrm{E}\right)$. Seriola dumerili (Risso, 1810) (amberjack), Arius graeffei Kner and Steindachner, 1867 (fork-tailed catfish), Tragulichthys jaculiferus (Cuvier, 1818) (longspine burrfish) and Aptychotrema rostrata (Shaw and Nodder, 1794) (eastern shovelnose ray) were caught by angling in Moreton Bay $\left(27^{\circ} 25^{\prime} \mathrm{S} 153^{\circ} 12^{\prime} \mathrm{E}\right)$. Dasyatis kuhlii (Müller and Henle, 1841) (blue-spotted whipray) were caught by seine net at Hays Inlet $\left(27^{\circ} 07^{\prime} \mathrm{S} 153^{\circ} 04^{\prime} \mathrm{E}\right)$. Trachinotus baillonii (Lacépède, 1801) (smallspotted dart) were caught by angling from Forty-mile beach $\left(24^{\circ} 22^{\prime} \mathrm{S} 153^{\circ} 82^{\prime} \mathrm{E}\right)$. Anguilla reinhardtii Steindachner, 1867 (long-finned eel) were caught by hand-net in the lake at University of Queensland, St. Lucia, and Megalops cyprinoides (Broussonet, 1782) (Pacific tarpon) were caught by angling at Colleges Crossing in the Brisbane River. Scleropages leichardti Günter, 1864 (Southern saratoga) were purchased from a commercial fish farm in Queensland, Acipenser gueldenstaedtii Brandt and Ratzeberg, 1833 (Russian sturgeon) were purchased from an aquarium fish retailer in Denmark, and Neoceratodus forsteri (Krefft, 1870) (Australian lungfish) were obtained from breeding stock at Macquarie University, Sydney (Table 1).
Table 1 Taxonomic position, mass and length of experimental animals. Body mass $(B M)$, fork length $(F L)$ and total length $(T L)$ of experimental animals. A no or yes in the secondary vascular system (SVS) column denotes the presence or absence of a SVS in that species

\begin{tabular}{|c|c|c|c|c|c|}
\hline Species & Family & $\begin{array}{l}\text { BM } \\
\text { (g) }\end{array}$ & $\begin{array}{l}\text { FL } \\
(\mathrm{cm})\end{array}$ & $\begin{array}{l}\text { TL } \\
(\mathrm{cm})\end{array}$ & SVS \\
\hline \multicolumn{6}{|l|}{ Chondrichthyes } \\
\hline $\begin{array}{l}\text { Aptychotrema rostrata } \\
\text { Dasyatis kuhlii } \\
\text { Hemiscyllium ocellatum }\end{array}$ & $\begin{array}{l}\text { Rhinobatidae } \\
\text { Dasyatidae } \\
\text { Hemiscylliidae }\end{array}$ & $\begin{array}{l}356 \\
184 \\
434\end{array}$ & $\begin{array}{l}- \\
- \\
-\end{array}$ & $\begin{array}{l}51 \\
30 \\
57\end{array}$ & $\begin{array}{l}\text { No } \\
\text { No } \\
\text { No }\end{array}$ \\
\hline \multicolumn{6}{|l|}{ Chondrostei } \\
\hline $\begin{array}{l}\text { Acipenser gueldenstaedtii } \\
\text { Teleostei }\end{array}$ & Acipenseridae & 602 & 46 & 51 & Yes \\
\hline $\begin{array}{l}\text { Scleropages leichardti } \\
\text { Megalops cyprinoides } \\
\text { Anguilla reinhardtii } \\
\text { Conger cinereus } \\
\text { Arius graeffei } \\
\text { Halophryne diemensis } \\
\text { Pseudocaranx dentex } \\
\text { Seriola dumerili } \\
\text { Trachinotus bailllonii } \\
\text { Echeneis naucrates } \\
\text { Gymnocranius audleyi } \\
\text { Lutjanus fulviflammus } \\
\text { Scarus schlegeli } \\
\text { Tragulichtys jaculiferus }\end{array}$ & $\begin{array}{l}\text { Osteoglossidae } \\
\text { Megalopidae } \\
\text { Anguillidae } \\
\text { Congridae } \\
\text { Ariidae } \\
\text { Batrachoididae } \\
\text { Carangidae } \\
\text { Carangidae } \\
\text { Carangidae } \\
\text { Echeneidae } \\
\text { Lethrinidae } \\
\text { Lutjanidae } \\
\text { Scaridae } \\
\text { Diodontidae }\end{array}$ & $\begin{array}{r}80 \\
469 \\
995 \\
492 \\
448 \\
304 \\
521 \\
318 \\
128 \\
254 \\
343 \\
436 \\
467 \\
255\end{array}$ & $\begin{array}{l}- \\
33 \\
- \\
- \\
28 \\
- \\
27 \\
31 \\
21 \\
- \\
24 \\
- \\
- \\
-\end{array}$ & $\begin{array}{r}23 \\
38 \\
72 \\
73 \\
31 \\
217 \\
32 \\
35 \\
24 \\
44 \\
27 \\
29 \\
30 \\
19\end{array}$ & $\begin{array}{l}\text { Yes } \\
\text { Yes } \\
\text { Yes } \\
\text { Yes } \\
\text { Yes } \\
\text { Yes } \\
\text { Yes } \\
\text { Yes } \\
\text { Yes } \\
\text { Yes } \\
\text { Yes } \\
\text { Yes } \\
\text { Yes } \\
\text { Yes }\end{array}$ \\
\hline \multicolumn{6}{|l|}{ Dipnoi } \\
\hline Neoceratodus forsteri & Ceratodontidae & 255 & - & 28 & No \\
\hline
\end{tabular}




\section{Surgical procedures}

Fish were anaesthetised in either MS-222 $\left(0.5 \mathrm{~g} \mathrm{l}^{-1}\right)$ or benzocaine $\left(0.06 \mathrm{~g} \mathrm{l}^{-1}\right)$ until respiratory movement ceased and animals were unresponsive to tactile stimulation. The pericardium was exposed by a midline incision between the pectoral fins, and heparin (approximately 3,000 IU kg-1 body mass; Sigma Chemicals) in $0.9 \% \mathrm{NaCl}$ was injected into the heart. Heparin was allowed to circulate for a few minutes before a small incision was made in the ventricle, through which a length of flared polyethylene tubing was guided into the bulbus/conus arteriosus. The cannula was secured with a suture around the junction of the ventricle and bulbus/conus, and the sinus venosus opened to allow free drainage of fluid returning to the heart. Animals were flushed with an appropriate fish Ringer containing $25 \mathrm{IU}$ heparin $\mathrm{ml}^{-1}$, by hand-pressure or by use of a drip-bag with a $60-\mathrm{cm}$ pressure-head. All perfusion and casting was performed while animals were submersed in water. The smooth muscle relaxant papaverine $\left(20 \mathrm{mg} \mathrm{kg}^{-1}\right)$ was administered through the injection port of the perfusion line when the effluent appeared to contain few red blood cells, and again when effluent was clear of red blood cells. Flushing was then discontinued, and Mercox (CL-2B; Vilene Hospital, Tokyo, Japan) mixed with methyl methacrylate monomer (BDH Laboratory Supplies, Poole, $\mathrm{UK}$ ) in a $4: 1$ ratio containing $5 \mathrm{mg}$ catalyst $\mathrm{g}^{-1}$ (Vilene Hospital), was injected by moderate hand pressure. Following polymerisation (approximately $24 \mathrm{~h}$ at $>25^{\circ} \mathrm{C}$ ), the tissues overlying the cast were removed in one or more changes of 20-25\% (w/v) $\mathrm{KOH}$ over 510 days. Vascular casts were subsequently rinsed in running tap water, cleaned in $5 \% \mathrm{HNO}_{3}$ for $24 \mathrm{~h}$, rinsed in distilled water and

Table 2 Occurrence of interarterial anastomoses (iaas). (e.b.a. Efferent branchial artery, a.m.a. s.v. side vessel of the afferent mandibular artery, a.c.ext. external carotid artery, a.c.int. internal carotid artery, p.a.psb.a. primary afferent pseudobranchial artery, allowed to dry before examination under a dissection microscope (WILD M3Z; Heerbrugg, Switzerland). The presence of iaas on different vessels could be determined at a magnification of $\times 250$. For the quantitative assessment of iaas, relevant vessels from selected species were mounted on scanning electron microscope (SEM) stubs with double-sided carbon tape. These samples were sputter coated on an IB5 platinum coater (Eiko Engineering, Japan) at $6 \mathrm{~mA}$ for $3 \mathrm{~min}$ and viewed on a JSM-6400F field emission SEM (Jeol, Tokyo, Japan) with an acceleration voltage of $15 \mathrm{kV}$. Micrographs of adjacent sections were captured digitally at a resolution of $1,024 \times 768$ pixels

\section{Results}

No evidence was found for the presence of iaas at any arterial site in the elasmobranchs $H$. ocellatum, $A$. rostrata and $D$. kuhlii, or the dipnoan $N$. forsteri. In all other species examined, a SVS was present.

A SVS was present in the chondrostean, A. gueldenstaedtii, with iaas occurring on the postlamellar circulation, carotid arteries, pseudobranchial arteries, dorsal aorta and segmental arteries (Table 2).

In $T$. jaculiferus, no evidence for iaas was found on any systemic vessels, although the vascular cast was of sufficient quality to display endothelial cell nuclear

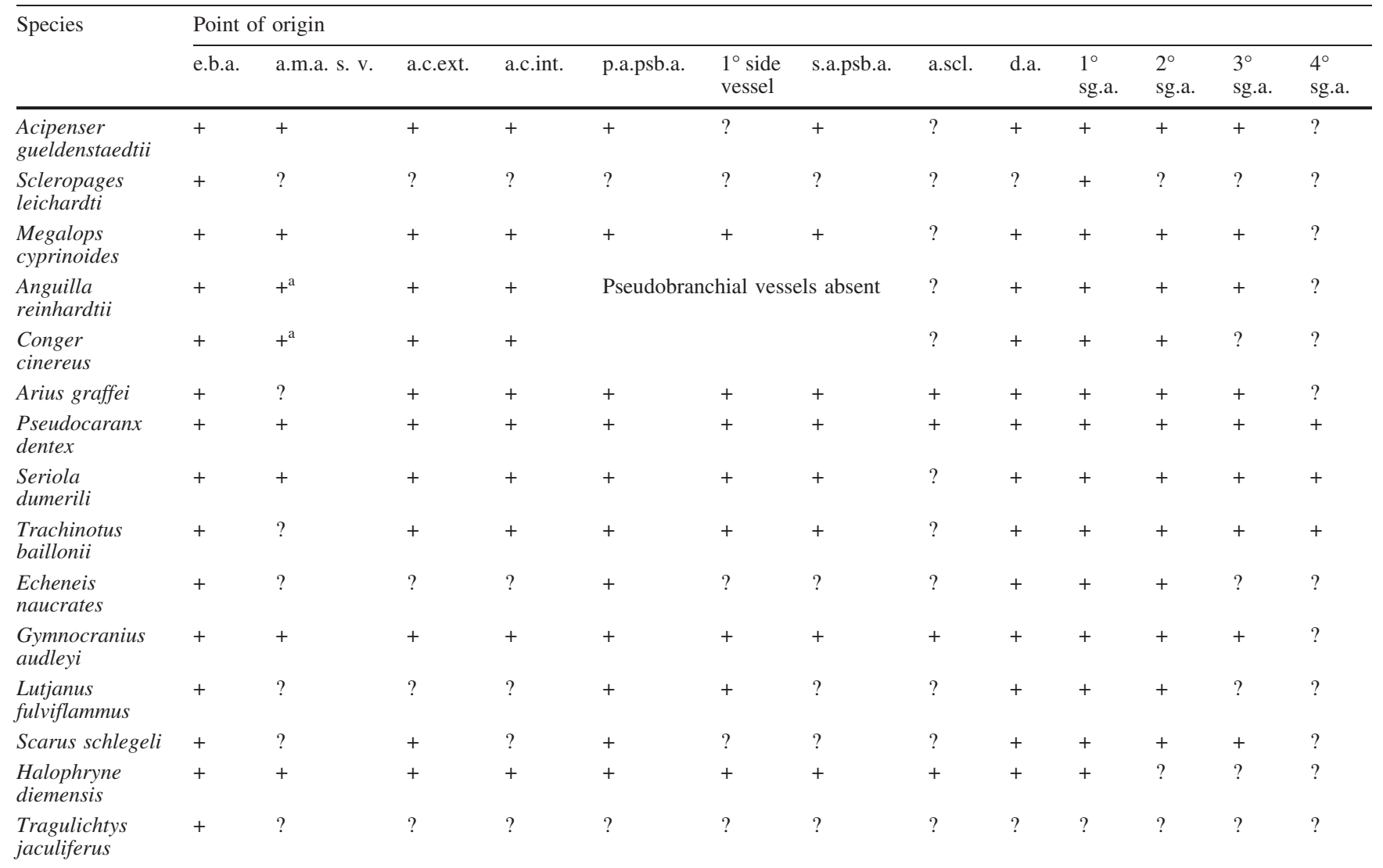

s.a.psb.a. secondary afferent pseudobranchial artery, a.scl. subclavian artery, d.a. dorsal aorta, sg.a. segmental artery, $1^{\circ}-4^{\circ}$ level of branching from the primary vessel, + iaas present, - iaas absent, ? no observations made)

\footnotetext{
${ }^{a}$ Interarterial anastomoses appear directly on the a.m.a.
} 
Fig. 1a, b Scanning electron micrographs of vascular casts of the postlamellar circulation in the longspine burrfish, Tragulichtys jaculiferus. a Low magnification micrograph of the efferent vessels of the first gill arch. b Efferent filamental arteries from bordered area in a, showing numerous interarterial anastomoses (iaas) on both efferent filamental (EFA) and efferent branchial arteries $(E B)$ giving rise to several secondary vessels $(S V)$ running in parallel to the primary vessels
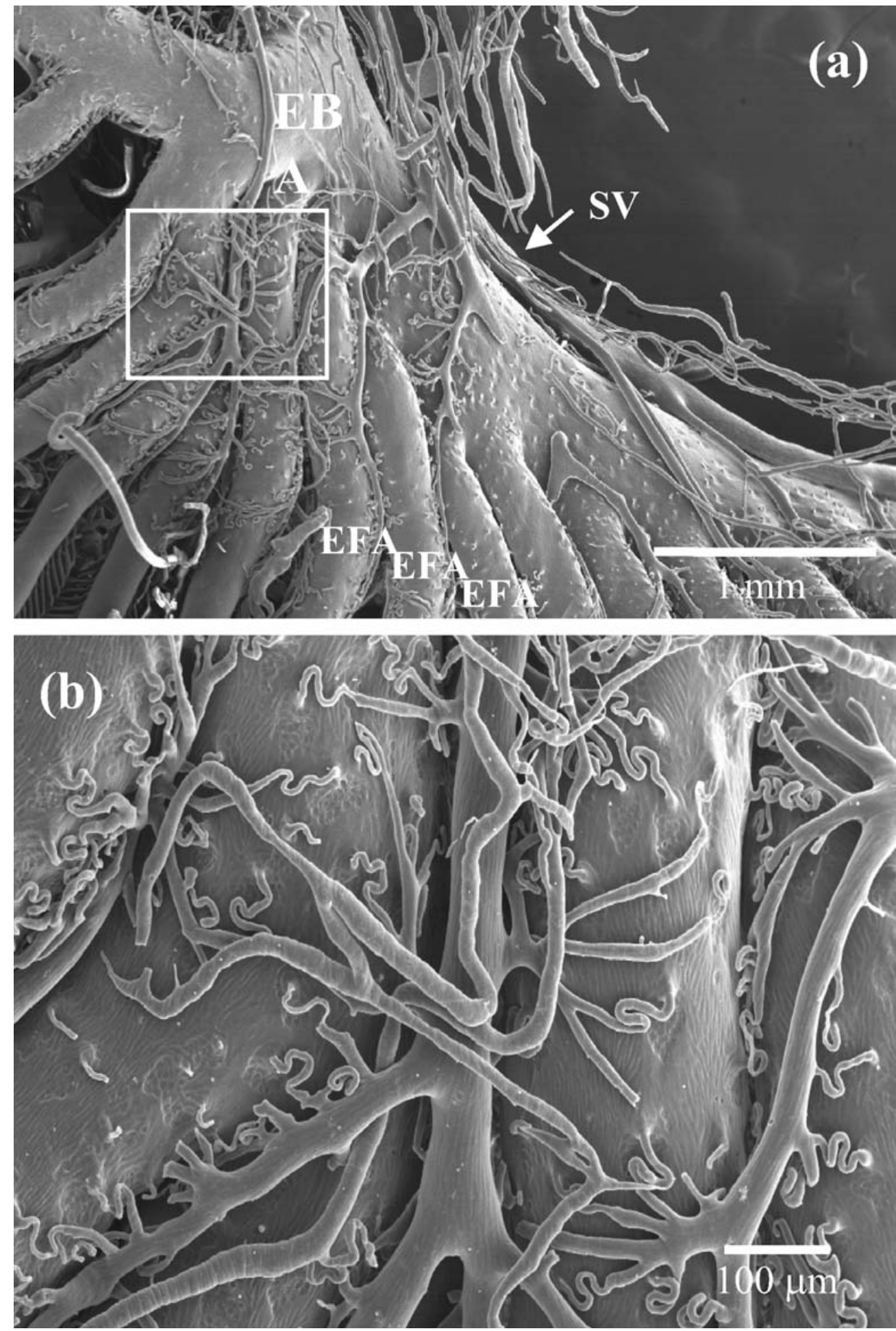

imprints. Interarterial anastomoses, however, were present at high densities on the postlamellar (efferent filamental and branchial) arteries. The numerous, small diameter vessels coalesced to form large bore secondary vessels that ran parallel to the efferent branchial arteries to the roof of the buccal cavity (Fig. 1a, b).

In $S$. leichardti the segmental arteries gave rise to only 5-20 iaas each (Fig. 2a, b). These iaas were always found, in clusters, a few millimetres from the dorsal aorta and, as such, only located on first order $\left(1^{\circ}\right)$ segmental arteries of relatively large dimensions $(200 \mu \mathrm{m}+)\left(1^{\circ}\right.$ is the main segmental vessel; with the hierarchy of vessels indicated by the order in which they branch off: $2^{\circ}, 3^{\circ}$, etc.). Anastomoses were also found on the efferent branchial arteries (Fig. 2c), but on no other vessels in the head region. 

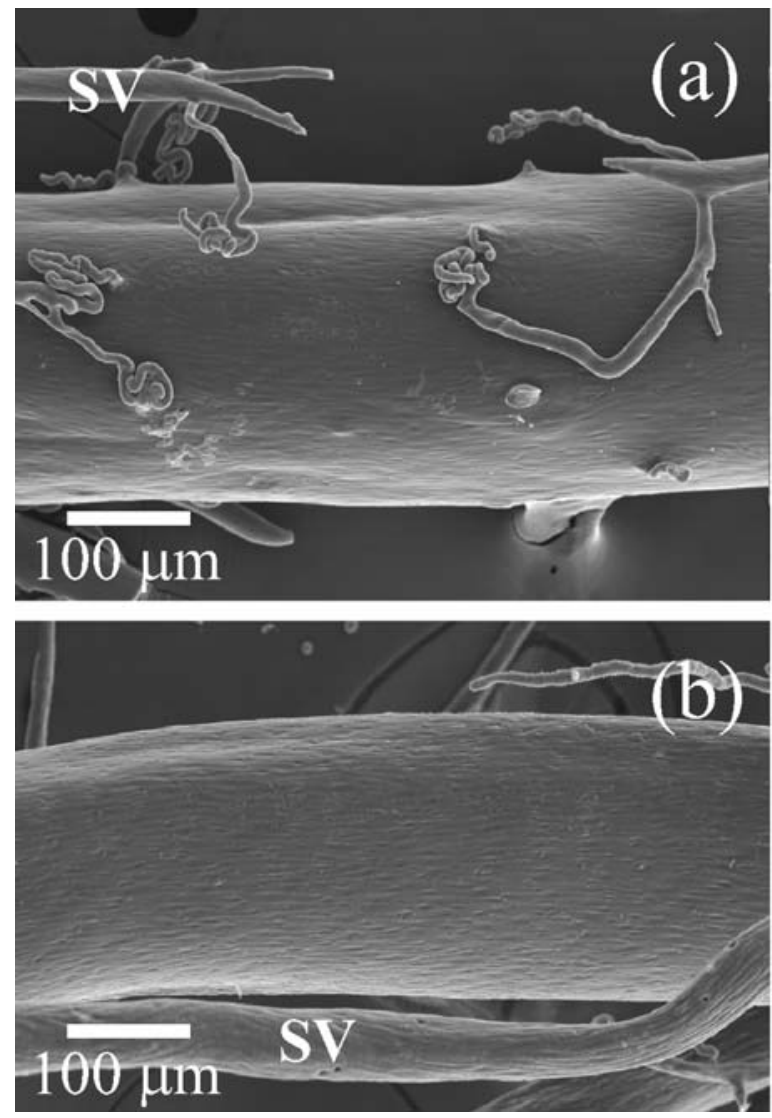

Fig. 2a-c Scanning electron micrographs from saratoga, Scleropages leichardti. a First order ventral segmental artery, approximately $1 \mathrm{~mm}$ from dorsal aorta, showing most of the iaas found on that vessel. b Same vessels, approximately $5 \mathrm{~mm}$ from a. The

In the remaining actinopterygian species iaas were found to originate from a number of different vessels, including the internal and external carotid arteries, the subclavian artery, side vessels of the afferent mandibular artery, and the primary and secondary afferent pseudobranchial arteries.

With the exception of T. jaculiferus and S. leichardti, the origin of iaas from the efferent branchial and filamental arteries, dorsal aorta, segmental arteries, internal and external carotid arteries and the primary afferent pseudobranchial artery was a common feature for all species that had a SVS. In A. reinhardtii and $C$. cinereus, iaas originated directly from the afferent mandibular arteries. Some interspecific variation occurred in relation to whether iaas were present on side vessels of the afferent mandibular artery, on the secondary afferent pseudobranchial artery, and to the order of segmental artery branching that iaas arose from (Table 2).

Anastomoses were found on up to fourth order $\left(4^{\circ}\right)$ segmental arteries only in the three carangid species, whereas iaas were typically only found on up to $2^{\circ}$ or $3^{\circ}$ segmental arteries in other species. Interarterial anastomoses on the $1^{\circ}$ segmental artery connect to a larger secondary vessel with a flow in the same direction as that of the primary vessel from which they originated. This

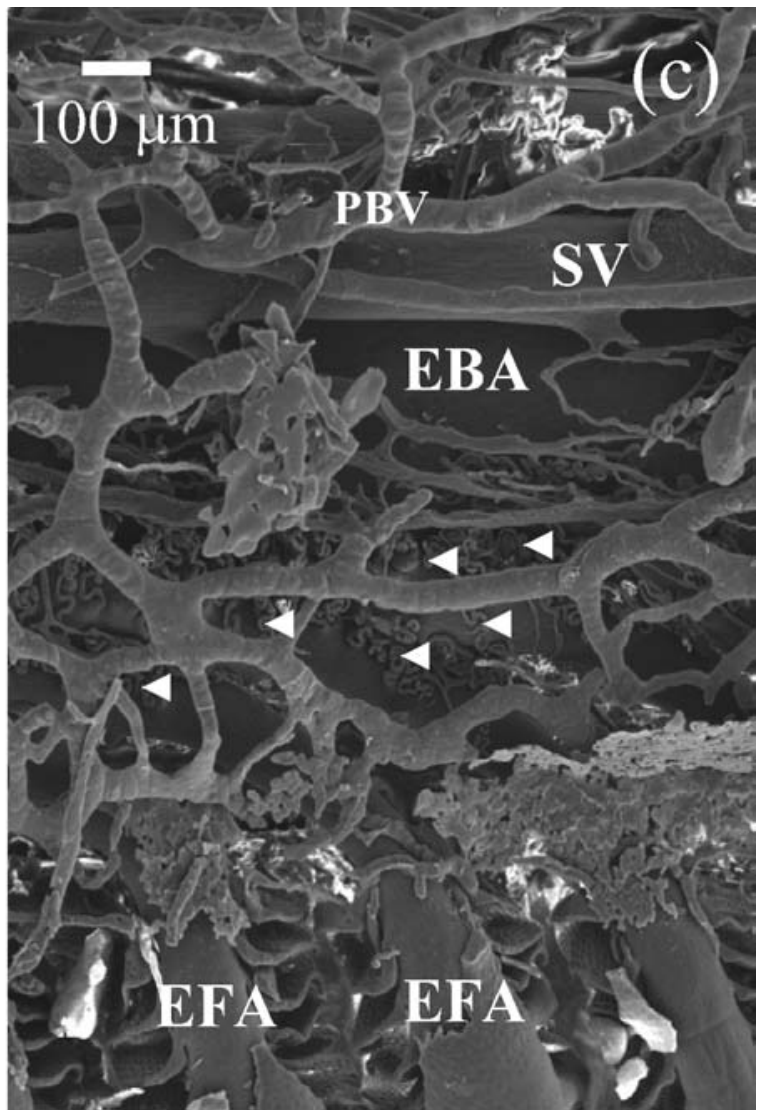

secondary vessel $(S V)$ has received no further supply since a. c Efferent branchial artery $(E B A)$ surrounded by peribranchial vessels $(P B V)$ with iaas (arrowheads) originating from the efferent filamental arteries $(E F A)$ and EBA

occurs either directly, or via short vessels formed by a group of anastomoses. However, where iaas originate from $2^{\circ}$ to $4^{\circ}$ segmental arteries they form secondary vessels with a flow that is initially in the opposite direction to that of the vessels from which they originate. This persists until reaching a secondary vessel in parallel to a $1^{\circ}$ segmental vessel, with which it anastomoses. In the species where iaas were present on $3^{\circ}$ and $4^{\circ}$ segmental arteries, these anastomoses appeared only on the most proximal part of those vessels.

Not all vessels of a suitable size gave rise to iaas. For example where two $2^{\circ}$ segmental arteries of similar size are derived from opposing sides of a $1^{\circ}$ segmental artery, one may give rise to iaas, while the other will not. Anastomoses may arise from the artery wall immediately after the vessel branches, or they may not appear until a few millimetres along the vessel. The distribution of iaas may not always be even around the circumference of an artery, but may occur bilaterally and occasionally unilaterally. Vascular casts clearly showed that as arteries tapered the origins of iaas could disappear abruptly, gradually decrease in frequency, along the vessel length, or occur in clusters of diminishing size (Fig. 3a). Most commonly vessels would coil extensively (Fig. 3b) before re-anastomosing with neighbouring secondary vessels, 
Fig. 3a-c Scanning electron micrographs of vascular casts of segmental arteries showing a clustered arrangement of iaas in Trachinotus baillonii, b extensive coiling of anastomoses in Arius graeffei and $\mathbf{c}$ the relative linear path of anastomoses in Seriola dumerili
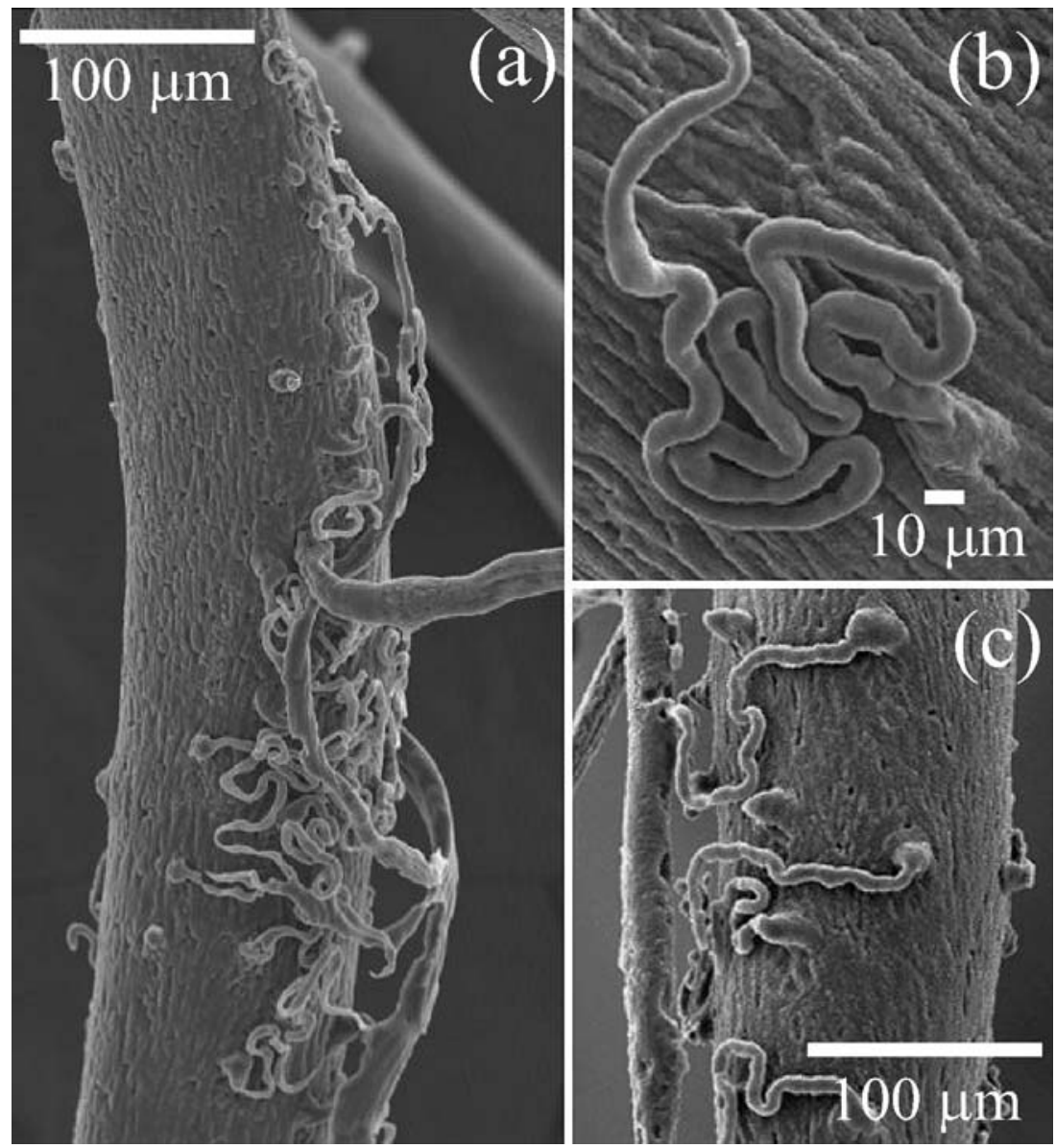

but would in some instances follow a relatively linear path (Fig. 3c). The latter appeared common for anastomoses derived from the postlamellar circulation (Fig. 1b).

Interarterial anastomoses originated from segmental vessels ranging from about 30 to $520 \mu \mathrm{m}$ in diameter, with some interspecific variation; iaas arose from vessels of a smaller diameter in the Perciformes, compared with the Siluriformes and Anguilliformes. The mean frequency of iaas (f iaa $\mathrm{mm}^{-1}$ of artery) ranged from 45 to 127 , and did not change markedly with vessel size, except in $A$. reinhardtii, where they increased in frequency, with increasing vessel diameter. The mean density of iaas ranged from 70 to 442 iaas $\mathrm{mm}^{-2}$ vessel wall. Because iaas originated from small diameter vessels and at high frequencies in the Carangidae, the small diameter vessels had iaa densities occasionally in excess of 1,000 per $\mathrm{mm}^{-2}$ of arterial wall (Fig. 4a-c). Arius graeffei had the lowest mean frequency of iaas of $45 \mathrm{~mm}^{-1}$, and as a consequence also had the lowest mean density of 70 iaas $\mathrm{mm}^{-2}$. Anguilla reinhardtii had the highest frequency of anastomoses, with a maximum of 310 iaas $\mathrm{mm}^{-1}$, but as iaas did not occur on segmental arteries with a diameter of less than $58 \mu \mathrm{m}$ their average density was only 224 iaas $\mathrm{mm}^{-2}$.

In the Perciformes a large proportion (60-80\%) of iaas are derived from segmental arteries with a diameter smaller than $200 \mu \mathrm{m}$ (Fig. 4a-d), while in A. graeffei about $70 \%$ were derived from vessels with a diameter of 150-300 $\mu \mathrm{m}$ (Fig. 4e), and in A. reinhardtii $70 \%$ were derived from vessels in the 100-250 $\mu \mathrm{m}$ range (Fig. 4f).

The relative contribution (RC) percentage and mean density of iaas in the individual vessel diameter groups was used to calculate the relative amount of secondary vessel vascularisation in the body (i.e. degree of investment, DI):

$\mathrm{DI}=\sum$ mean $\left[\right.$ fiaamm $\left.^{-2}\right] \times$ mean $[\mathrm{RC}]$,

for all segmental artery size groups. A decreasing degree of investment in the systemic SVS was found to be:

Trachinotus $(100)>$ Pseudocaranx $(73)>$ Seriola $(63)$ $>$ Scarus $(52)>$ Anguilla $(46)>$ Arius $(16)>$ Scleropages $(1)$ $>$ Tragulichthys (0),

where DI for T. baillonii was used as index 100 .

Based on scanning electron micrographs, the length of vessel giving rise to iaas was determined for a series of segmental arteries from $A$. reinhardtii (segmental artery $n=13$ ) and $T$. baillonii $(n=8)$. In both species, the length of vessel from which iaas originated was proportional to the total length of vessel, and could be extrapolated to the entire animal. Examination, by light microscopy, of the entire vascular cast gave a gross validation of this extrapolation. The counts for density of iaas, and the 
Fig. 4a-f Left row Frequency (f) of iaas mm ${ }^{-1}$ vessel (solid bars) and density of iaas $\mathrm{mm}^{-2}$ vessel (open bars). Right row Relative contribution of iaas on segmental arteries of different size classes in a Pseudocaranx dentex, b Trachinotus baillonii, c Seriola dumerili, d Scarus schlegeli, e Arius graeffei and $\mathbf{f}$ Anguilla reinhardtii. Segmental arteries are divided into different size classifications according to their luminal diameter: 0 0-49 $\mu \mathrm{m}, 1$ 50-99 $\mu \mathrm{m}, 2$ 100$149 \mu \mathrm{m}, 3$ 150-199 $\mu \mathrm{m}, 4200$ $249 \mu \mathrm{m}, 5250-299 \mu \mathrm{m}, 6300$ $349 \mu \mathrm{m}, 7$ 350-399 $\mu \mathrm{m}, 8400$ $449 \mu \mathrm{m}, 9450-499 \mu \mathrm{m}, 10$ 500-549 $\mu \mathrm{m}$
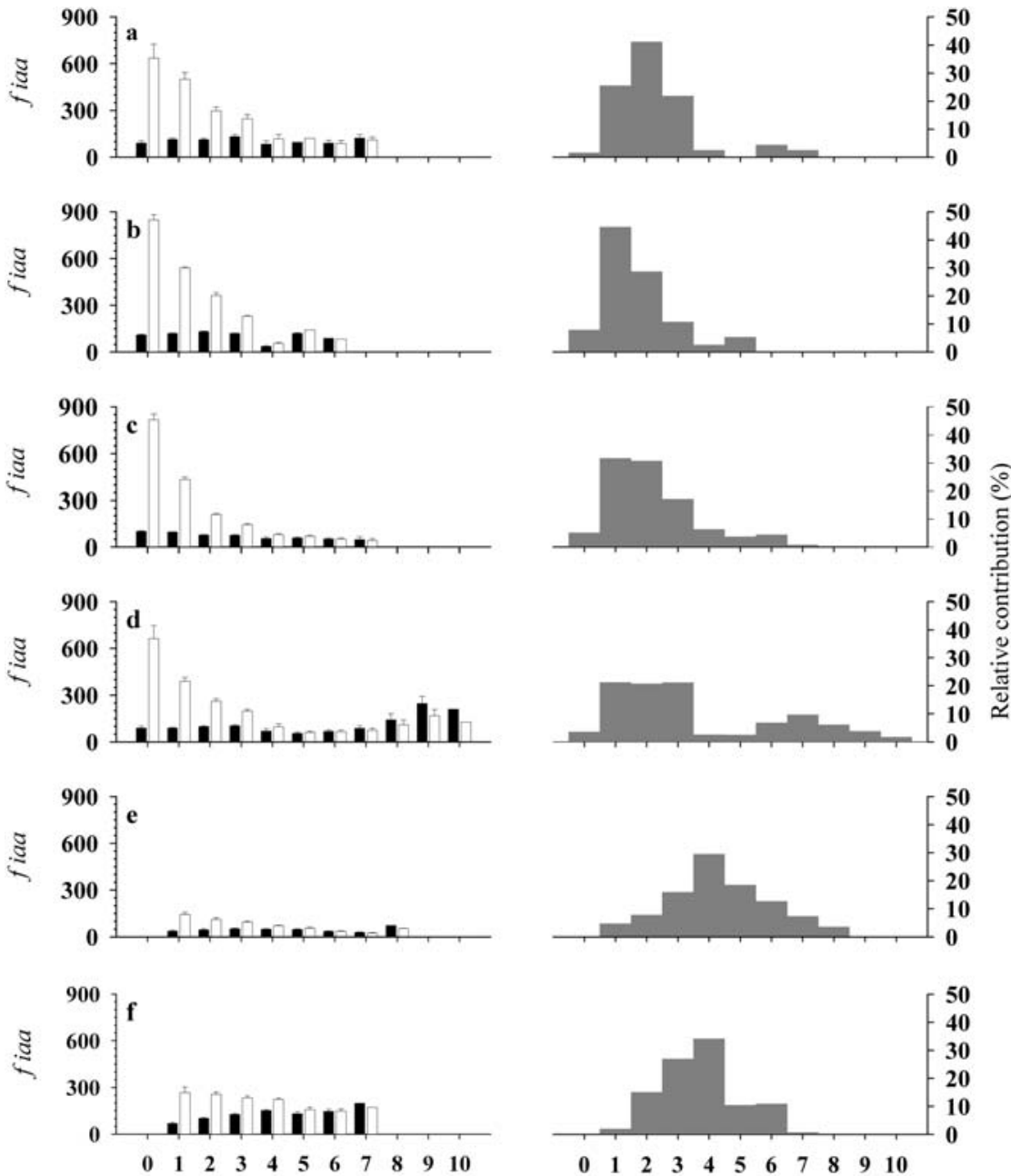

Segmental artery size classes

Table 3 Absolute number of iaas in the long-finned eel, $A$. reinhardtii and the smallspotted dart, $T$. baillonii. Length measurements indicate length of vessel giving rise to anastomoses, from a number of individual segmental arteries, and the corresponding number of iaas. For calculation of body surface area, $T$. baillonii was considered two-dimensional and $A$. reinhardtii cylindrical

\begin{tabular}{llcc}
\hline & & Anguilla reinhardtii $(n=13)$ & Trachinotus baillonii $(n=8)$ \\
\hline Dorsal & Length $(\mathrm{mm})$ & $8.6-26.1$ & $42.7-51.1$ \\
& iaas vessel & \\
\multirow{2}{*}{ Ventral } & Length $(\mathrm{mm})$ & $100-2,986$ & $4,277-5,891$ \\
& iaas vessel & -1 & $11.4-174.1$ \\
Total & & $829-3539$ & $1,148-13,370$ \\
& $\mathrm{~g}^{-1}$ body mass & 305,000 iaas & 221,200 iaas \\
& $\mathrm{cm}^{-2}$ body surface area & 307 & 1,728 \\
& 260 & 1,080 \\
\hline
\end{tabular}

length of vessel on which they occurred, revealed a significantly higher degree of secondary vascularisation in T. baillonii. This difference became even more obvious when extrapolating to the entire animal and comparing between species on a body mass or body surface area basis (Table 3 ).

\section{Discussion}

The morphology of iaas has been well described previously. They originate from various locations on arterial vessels as funnel-shaped openings with a diameter of 7 $15 \mu \mathrm{m}$ that gradually taper in to become vessels of capillary dimensions (Vogel and Claviez 1981). These iaas are slightly oval in their basal plane, with a width ranging from 12 to $26 \mu \mathrm{m}$, thus being slightly larger than the $7-15 \mu \mathrm{m}$ previously reported. There were no apparent 
differences in the general morphology of iaas between species, and with few exceptions, all anastomoses tended to follow quite tortuous path over $100-400 \mu \mathrm{m}$ before reanastomosing with other secondary vessels. Anastomoses derived from the postlamellar circulation commonly follow a more linear path to other secondary vessels (Fig. 1b).

Interarterial anastomoses, and thus a SVS, originate from a number of different arteries, many of which have not been documented previously as vessels of origin. In some species, secondary vessel origins are distributed throughout the head and in most regions of the trunk, resulting in a network of vessels that pervade many, but not all, parts of the body. The presence of iaas is restricted to arteries above a certain minimum diameter, but with no obvious limit to the maximum diameter.

The growth or genesis of iaas is unknown, as are any ontogenetic differences in the extent of a SVS that may occur. It could be argued that large individuals should possess a lower frequency of anastomoses $\left(\right.$ f ia $\mathrm{mm}^{-2}$ ) on their blood vessels, than smaller individuals of the same species, if segmental arteries grow with increasing body size and the number of iaas remains fixed. In general, this principle of lower densities on larger vessels appears to be supported (within each individual species) by the results in this study (Fig. 4). However, in S. schlegeli the largest arteries bearing iaas had higher densities than intermediate-sized vessels. While this is not unequivocal evidence of a dynamic SVS, it suggests that new iaas can be generated and link to the pre-existing system during growth. This is also supported by the absence of anastomoses on vessels smaller than a certain diameter. A study of an ontogenetic series, of a single species would provide more information on this point.

The distributional pattern of iaas in the Chondrostei is identical to that found in the Perciformes. Acipenser gueldenstaedtii shows a heavy investment in anastomoses that have the same morphologies as in the Perciformes, throughout the vascular system, with nothing to suggest that the SVS could be considered more primitive.

When considering the distributional pattern of iaas in the representatives from the 12 higher taxa of Actinopterygii that possessed a SVS in this study, there is little evidence to suggest that this specialised vascular system has arisen from community of descent. Although the presence of this vessel system appears to be a plesiomorphic character for all Actinopterygii, the data obtained from the present study clearly shows a high species-specific adaptation, not necessarily becoming more derived in modern teleosts. This is evident from vascular casts of the two species in this study showing a large degree of homogeneity in iaa distribution, namely the Saratoga S. leichardti and the longspine burrfish, $T$. jaculiferus. These two belong to taxa that are, from fossil evidence, considered to have evolved approximately 50 million years apart, in the early and late stages of teleost evolution, respectively (Lauder and Liem 1983). They both show a minimum investment in a SVS, yet the species that appeared within this period show significant- ly higher and different patterns in their secondary vascularisation.

\section{Physiological implications}

The frequency and density of iaas in relation to vessel size also demonstrate considerable interspecific differences regarding the degree of investment in a SVS. The perciform species in this study had a significantly higher frequency $\left(f i a a \mathrm{~mm}^{-1}\right)$ and density $\left(f i a \mathrm{~mm}^{-2}\right)$ of iaas than did the anguilliform or siluriform species, however, as the physiological function(s) of the SVS have not been unambiguously determined, these interspecific differences are difficult to interpret. However, it implies that the secondary vessel system is of variable importance. Our findings may prove useful in ascribing a function to the SVS, based on the physiology or behaviour of the different species. In $P$. dentex, $S$. dumerili and $T$. baillonii, iaas occur not only with a higher density on small diameter vessels, but also the majority of iaas occurred on small diameter vessels, and the lengths of individual segmental vessels giving rise to iaas are greater. These three species are all extreme carangiform swimmers with high aspect ratio tails and narrow caudal peduncles, characteristic of continuous cruising swimmers (Lindsey 1978; Webb 1997). This apparent correlation between degree of secondary vascularisation and activity levels, or scope for aerobic activity, is also conspicuous for the Osteoglossidae and the Diodontidae. The latter, having no iaas originating from the systemic vasculature, employs undulating pectoral fins for locomotion (Breder 1926), with the caudal fin only recruited to provide thrust during burst swimming (Arreola and Westneat 1996). Scleropages leichardti uses its unpaired (dorsal and anal) fins for propulsion during routine activity, has only a negligible quantity of red muscle to power body undulations and is suspected of having a low scope for aerobic activity (Wells et al. 1997). These findings further support the suggestion that the degree of secondary vascularisation is not exclusively linked to phylogenetic position, but rather appears to be related to the physiological adaptation of the species.

In no species were iaas observed on the coeliac, mesenteric or renal arteries, suggesting that the SVS plays no role in the visceral system. This is consistent with experimental evidence for G. morhua where the rate of flow through the SVS during food assimilation was significantly reduced (Skov and Steffensen, unpublished observations). However, this is in contrast to the current concept on the vascular arrangement in typical waterbreathing teleost fishes (Vogel 1985; Steffensen and Lomholt 1992), where the SVS is considered to supply the intestinal tract. Thus, Fig. 4 in Vogel (1985), which is widely used to illustrate supply of the SVS, should be revised.

The presence of an intrafilamental arteriovenous vascular arrangement was believed to be indicative of the presence of a systemic SVS (Vogel et al. 1998). This 
part of the vascular system is commonly referred to as the branchial SVS. Olson (2002) suggests that these vessels be subdivided into two pathways, the interlamellar (CVS) and the nutrient system. For some time, it has been known that the elasmobranch species have a branchial nonrespiratory vascular system in the form of a central venous sinus supplied through arteriovenous anastomoses on the efferent filamental arteries (Laurent and Dunel 1980; Olson and Kent 1980; Laurent 1984; Chopin et al. 1998). However, Chopin et al. (1998) reported that a systemic SVS is absent in the elasmobranch Carcharhinus melanopterus (Quoy and Gaimard, 1824). This observed lack of a secondary vessel system in Elasmobranchii is supported by the lack of evidence of iaas in both the major divisions of this group: the Selachiomorpha (H. ocellatum) and Rajiformes (D. kuhlii and $A$. rostrata). Similarly, the Dipnoi (Protopterus sp. and Lepidosiren sp.) have intrafilamental nutrient vessels, also derived from the efferent filamental arteries (Laurent and Dunel 1980; Morgan and Wright 1989), but lack a SVS (Chopin et al. 1998). Despite this, and the fact that a SVS has never been demonstrated in a species outside the Actinopterygii, the assumption has been that a systemic SVS was present throughout the Chondrichthyes and Osteichthyes.

\section{Conclusion}

Recently the presence of a non-respiratory vasculature within the filament body of the coelacanth (Latimeria chalumnae Smith, 1939) gill has been interpreted as evidence for a systemic SVS (Vogel et al. 1998). In our opinion, the presences of non-respiratory vessels in the gill filaments do not lend support to the presence of a systemic SVS. According to Fig. 2 in Olson (2002) nutrient vessels originate on the basal part of the efferent branchial artery and run retrograde to the primary (filamental) artery, to supply nutrient vessels within the filament. While it cannot be ruled out that secondary vessels originating from the efferent filamental and branchial arteries supply an intrafilamental vessel system, it is obvious from the SEM images, as seen in $T$. jaculiferus, that the majority of iaas give rise to secondary vessels running to the buccal cavity, and thus do not constitute an arteriovenous pathway, but an arterioarterial pathway. In our opinion, there is no basis to conclude that a systemic SVS is present, based on the presence of a central venous sinus. However, the so-called nutrient vessels (the other group of vessels contained in the definition 'arteriovenous circulation') are certainly part of the SVS, but are not arteriovenous. Thus in the case of the branchial circulation of $T$. jaculiferus, there appears to be two arterioarterial pathways and one venovenous.

With the exclusion of the intrafilamental vasculature (CVS) from the category of secondary vessels, the presence of a SVS appears to be highly phylogenetically restricted; a SVS is present in all teleostean and chondrostean species in this study, and has previously been found in two holostean species (Vogel and Claviez 1981). However, no evidence for a SVS has been found in Dipnoi or any Chondrichthyes species. It would appear then, that a SVS is restricted to the Actinopterygii in which it evolved to accommodate some feature of their physiology as they began to diverge from the Acanthodii some 400 million years ago.

Acknowledgements The Danish Research Agency, a University of Queensland Graduate School Award and Research Travel Award, the Elisabeth and Knud Petersens Foundation and Knud Højgaard Foundation are gratefully acknowledged in funding this study. The authors are indebted to Jean Joss, Macquarie University, for providing lungfish, as well as to Mr. Peter Kyne, Mr. Simon Pierce and Ms Tracey Turner for fieldwork assistance. Fish were collected under Queensland Government Department of Primary Industries, General Fisheries Permit number PRM02030C and Great Barrier Reef Marine Parks, Permit number G99/474. These experiments were approved by the University of Queensland Ethics Committee, UEAC permit number ANATDB/323/02/PHD.

\section{References}

Arreola VI, Westneat MW (1996) Mechanics of propulsion by multiple fins: kinematics of aquatic locomotion in the burrfish (Chilomycterus schoepfi). Proc R Soc Lond B 263:1689-1696

Breder CM (1926) The locomotion of fishes. Zoologica 4:159-297

Burne RH (1926) A contribution to the anatomy of the ductless glands and lymphatic system of the angler fish (Lophius piscatorius). Phil Trans R Soc Lond B 215:1-56

Burne RH (1929) A system of "fine" vessels associated with the lymphatics in cod (Gadus morrhua). Phil Trans R Soc Lond B 217:335-367

Chopin LK, Bennett MB (1996) Morphology and tyrosine hydroxylase immunohistochemistry of the systemic secondary vessel system of the blue catfish, Arius graeffei. J Morphol 229:347356

Chopin LK, Amey AP, Bennett MB (1998) A systemic secondary vessel system is present in the teleost fish Tandanus tandanus and absent in the elasmobranchs Carcharhinus melanopterus and Rhinobatus typus and in the dipnoan Neoceratodus forsteri. J Zool (Lond) 246:105-110

Dewar H, Brill RW, Olson KR (1994) Secondary circulation of the vascular heat exchangers in skipjack tuna, Katsuwonus pelamis. J Exp Zool 570:566-570

King JAC, Hossler FE (1986) The gill arch of the striped bass, Morone saxatalis. II. Microvasculature studied with vascular corrosion casting and scanning electron microscopy. Scan Electron Microsc 1986:1477-1488

Lahnsteiner F, Lametschwandtner A, Patzner RA (1990) The secondary blood vessel system of segmental arteries and dorsal aorta in Blennius pavo and Zosterisessor ophiocephalus. Histology, fine structure and SEM of vascular corrosion casts. Scan Microsc 4:111-124

Lauder GV, Liem KF (1983) The evolution and interrelationships of the actinopterygian fishes. Bull Mus Comp Zool 150:95-197

Laurent P (1984) Gill internal morphology. In: Hoar WS, Randall DJ (eds) Fish physiology, vol 10A. Gills. Academic, New York, pp 73-183

Laurent P, Dunel S (1980) Morphology of gill epithelia in fish. Am J Physiol 238:R147-R159

Lindsey CC (1978) Form, function, and locomotory habits in fish. In: Hoar WS, Randall DJ (eds) Fish physiology, vol 7. Locomotion. Academic, London, pp 1-100

Morgan M, Wright DE (1989) Morphology of central compartment and vasculature of the gills of Lepidosiren paradoxa (Fitzinger). J Fish Biol 34:875-888 
Munshi JSD, Roy PK, Ghosh TK, Olson KR (1994) Cephalic circulation in the air-breathing snakehead fish, Channa punctata, C. gachua, and C. marulius (Ophiocephalidae, Ophiocephaliformes). Anat Rec 238:77-91

Olson KR (1996) Secondary circulation in fish: anatomical organization and physiological significance. J Exp Zool 275:172-185

Olson KR (2002) Vascular anatomy of the fish gill. J Exp Zool 293:214-231

Olson KR, Kent B (1980) The microvasculature of the elasmobranch gill. Cell Tissue Res 209:49-63

Olson KR, Munshi JSD, Ojha J (1986) Gill microcirculation of the air-breathing climbing perch, Anabas testudineus (Bloch): relationships with the accessory respiratory organs and systemic circulation. Am J Anat 176:305-320

Olson KR, Munshi JSD, Ghosh TK, Ojha J (1990) Vascular organization of the head and respiratory organs of the airbreathing catfish, Heteropneustes fossilis. J Morphol 203:165179

Steffensen JF, Lomholt JP (1992) The secondary vascular system. In: Hoar HS, Randall DJ, Farrell AP (eds) Fish physiology, vol 12A. The cardiovascular system. Academic, San Diego, pp 185-217
Steffensen JF, Lomholt JP, Vogel WOP (1986) In vivo observations on a specialized microvasculature, the primary and secondary vessels in fishes. Acta Zool: 67:193-200

Vogel WOP (1981) Struktur und Organisationsprinzip im Gefässsystem der Knochenfische. Gegenbaurs Morphol Jahrb Leipzig 127:772-784

Vogel WOP (1985) Systemic vascular anastomoses, primary and secondary vessels in fish, and the phylogeny of lymphatics. In: Johansen K, Burggren WW (eds) Cardiovascular shunts, Alfred Benzon Symposium 21. Munksgaard, Copenhagen, pp 143-159

Vogel WOP, Claviez M (1981) Vascular specialization in fish, but no evidence for lymphatics. Z Naturforsch 36C:490-492

Vogel WOP, Hughes GM, Mattheus U (1998) Non-respiratory blood vessels in Latimeria gill filaments. Phil Trans R Soc Lond B 353:465-475

Webb PW (1997) Swimming. In: Evans DH (ed) The physiology of fishes. CRC Press, Boca Raton, pp 3-24

Wells RMG, Baldwin J, Seymour RS, Weber RE (1997) Blood oxygen transport and hemoglobin function in three tropical fish species from northern Australian freshwater billabongs. Fish Physiol Biochem 16:247-258 